Prepared in cooperation with the

Naval Air Station Patuxent River

\title{
Groundwater Quality and Occurrence and Distribution of Selected Constituents in the Aquia and Upper Patapsco Aquifers, Naval Air Station Patuxent River, St. Mary's County, Maryland, July 2008
}

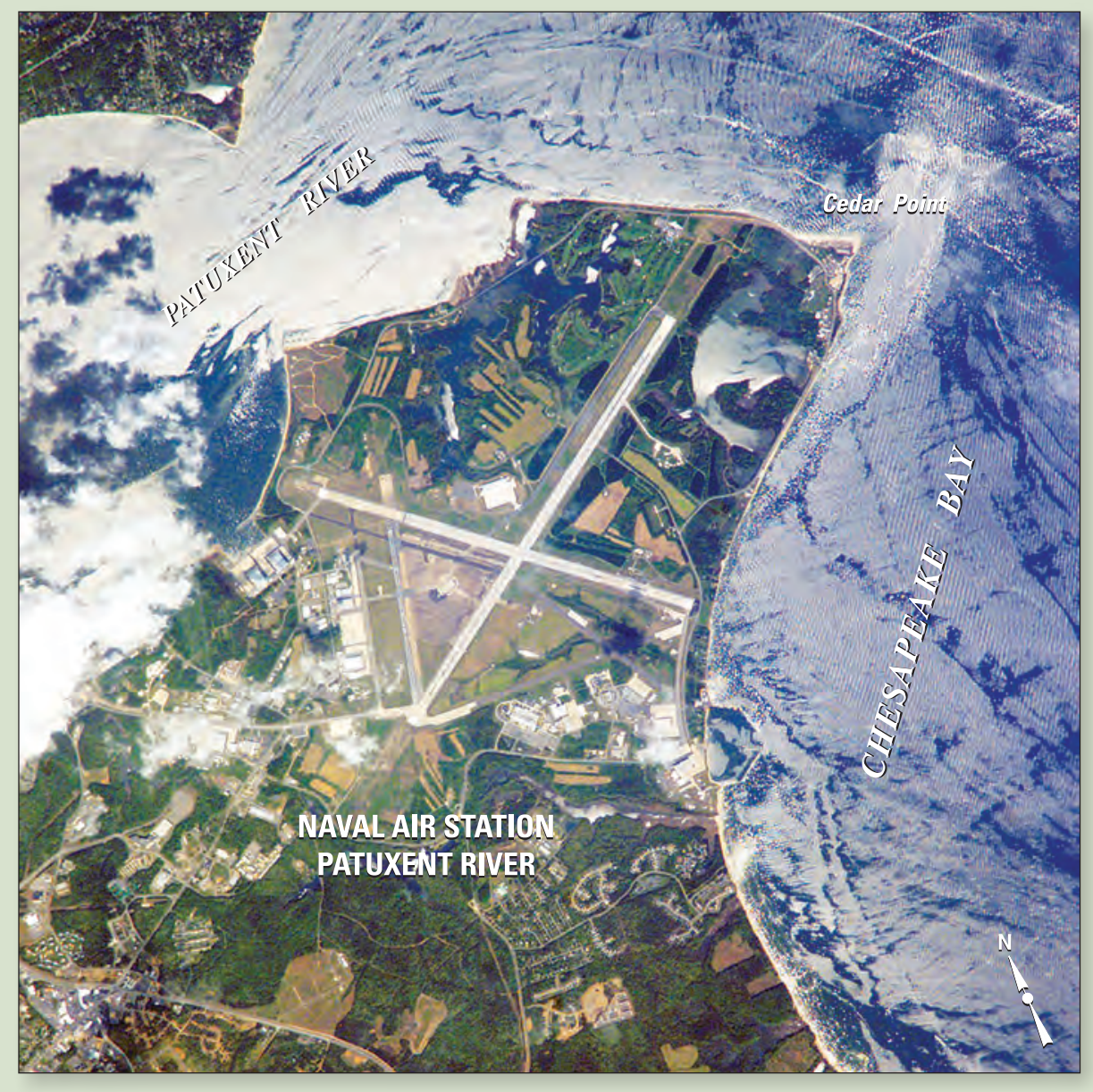

Scientific Investigations Report 2012-5011 
Cover. Aerial photograph of Naval Air Station Patuxent River taken by the National Aeronautics and Space Administration (NASA) International Space Station Program, April 28, 2007. 


\section{Groundwater Quality and Occurrence and Distribution of Selected Constituents in the Aquia and Upper Patapsco Aquifers, Naval Air Station Patuxent River, St. Mary's County, Maryland, July 2008}

By Cheryl A. Dieter, Kimberly W. Campo, and Anna C. Baker

Prepared in cooperation with the

Naval Air Station Patuxent River

Scientific Investigations Report 2012-5011 


\section{U.S. Department of the Interior \\ KEN SALAZAR, Secretary \\ U.S. Geological Survey \\ Marcia K. McNutt, Director}

U.S. Geological Survey, Reston, Virginia: 2012

For more information on the USGS - the Federal source for science about the Earth, its natural and living resources, natural hazards, and the environment, visit http://www.usgs.gov or call 1-888-ASK-USGS

For an overview of USGS information products, including maps, imagery, and publications, visit http://www.usgs.gov/pubprod

To order this and other USGS information products, visit http://store.usgs.gov

Any use of trade, product, or firm names is for descriptive purposes only and does not imply endorsement by the U.S. Government.

Although this report is in the public domain, permission must be secured from the individual copyright owners to reproduce any copyrighted materials contained within this report.

Suggested citation:

Dieter, C.A., Campo, K.W., and Baker, A.C., 2012, Groundwater quality and occurrence and distribution of selected constituents in the Aquia and Upper Patapsco aquifers, Naval Air Station Patuxent River, St. Mary's County, Maryland, July 2008: U.S. Geological Survey Scientific Investigations Report 2012-5011, 16 p. 


\section{Contents}

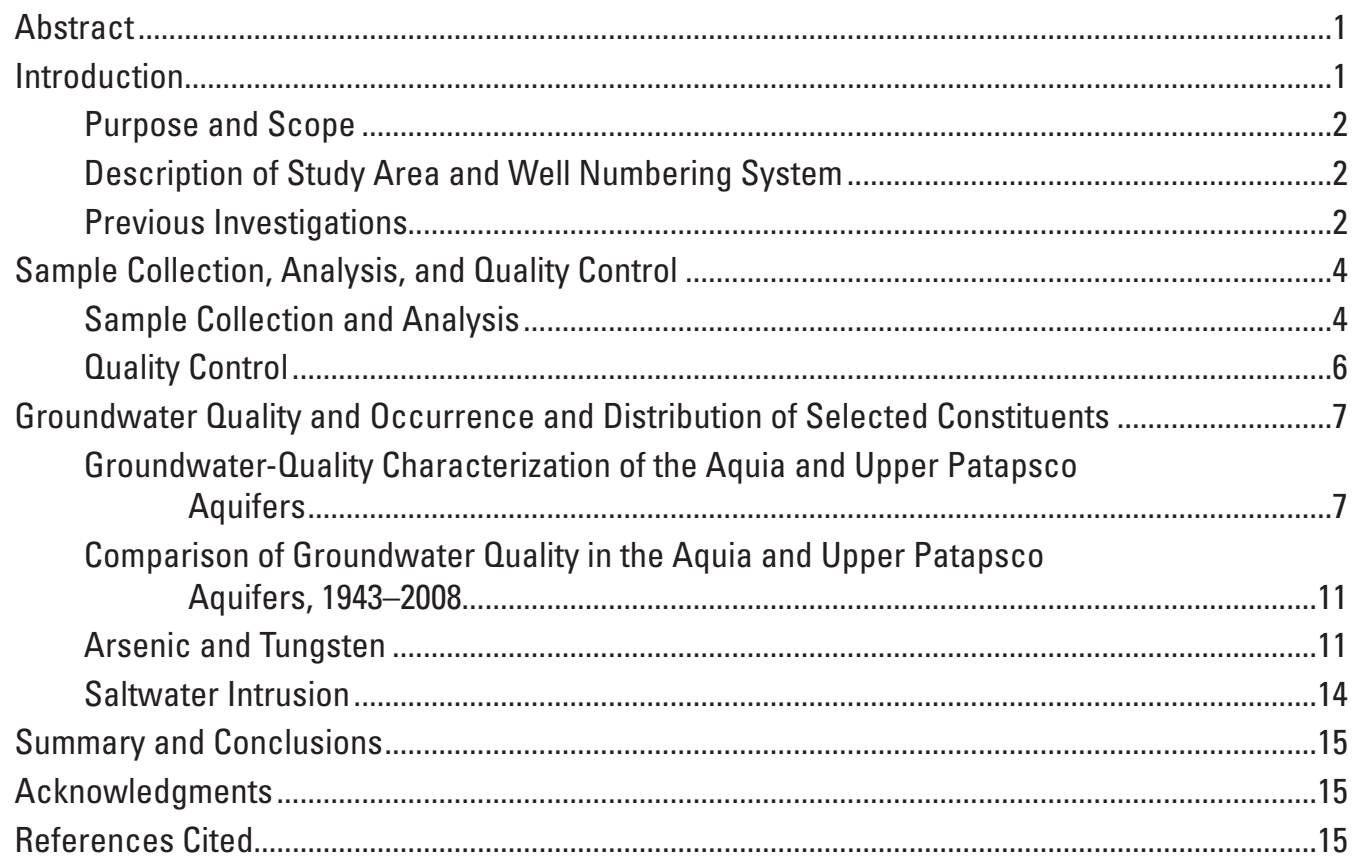




\section{Figures}

1-2. Maps showing-

1. Location of Naval Air Station Patuxent River, St. Mary's County, Maryland.

2. Selected well locations at Naval Air Station Patuxent River and

Webster Outlying Field, St. Mary's County, Maryland .5

3. Graphs showing comparisons of major ions in water samples collected from the Aquia and Upper Patapsco aquifers at the Naval Air Station Patuxent River (NASPR) and Webster Outlying Field (WOLF) locations in 1999-2001 and 2008

4. Piper diagram showing comparison of the average chemical composition of seawater to the chemical composition of groundwater from selected wells at Naval Air Station Patuxent River and Webster Outlying Field, St. Mary's County, Maryland

\section{Tables}

1. Hydrologic and corresponding geologic units at Naval Air Station Patuxent River and Webster Outlying Field, St. Mary's County, Maryland . .4

2. Records for selected wells at Naval Air Station Patuxent River and Webster Outlying Field, St. Mary's County, Maryland

3. Water-quality parameters with concentrations reported as estimated (E), justification for data qualifier, and long-term method detection levels (LT-MDLs) and laboratory reporting levels (LRLs) that bracket the estimated concentrations where applicable

4. Water quality and chemical composition of water samples collected from wells screened in the Aquia and Upper Patapsco aquifers, Naval Air Station Patuxent River and Webster Outlying Field, St. Mary's County, Maryland, July 2008 .

5. Comparison of average seawater and average connate water to groundwater samples collected in 2008 from the Aquia aquifer at Naval Air Station Patuxent River, and Webster Outlying Field, St. Mary's County, Maryland 


\section{Conversion Factors and Datums}

\begin{tabular}{lccc}
\hline & Multiply & By & To obtain \\
\hline & Length & \\
\hline foot $(\mathrm{ft})$ & 0.3048 & meter $(\mathrm{m})$ \\
\hline & Area & \\
\hline acre & 0.004047 & square kilometer $\left(\mathrm{km}^{2}\right)$ \\
\hline
\end{tabular}

Temperature in degrees Celsius $\left({ }^{\circ} \mathrm{C}\right)$ may be converted to degrees Fahrenheit $\left({ }^{\circ} \mathrm{F}\right)$ as follows:

$$
{ }^{\circ} \mathrm{F}=\left(1.8 \times{ }^{\circ} \mathrm{C}\right)+32
$$

Vertical coordinate information is referenced to the North American Vertical Datum of 1988 (NAVD 88).

Horizontal coordinate information is referenced to the North American Datum of 1983 (NAD 83).

Altitude, as used in this report, refers to distance above the vertical datum.

Specific conductance is given in microsiemens per centimeter at 25 degrees Celsius $(\mu \mathrm{S} / \mathrm{cm}$ at $\left.25^{\circ} \mathrm{C}\right)$.

Concentrations of chemical constituents in water are given either in milligrams per liter (mg/L) or micrograms per liter ( $\mu \mathrm{g} / \mathrm{L})$. 



\title{
Groundwater Quality and Occurrence and Distribution of Selected Constituents in the Aquia and Upper Patapsco Aquifers, Naval Air Station Patuxent River, St. Mary's County, Maryland, July 2008
}

\author{
By Cheryl A. Dieter, Kimberly W. Campo, and Anna C. Baker
}

\section{Abstract}

The Naval Air Station Patuxent River in southern Maryland has continued to expand in the first decade of the 21 st century, contributing to rapid population growth in the surrounding area. The increase in population has caused State and County water managers and others to be concerned about the impact of population growth on the quantity and quality of groundwater supplies. The U.S. Geological Survey has been investigating the groundwater resources of the air station since 1998. As part of that ongoing investigation, groundwater was sampled in 2008 in six wells in the Aquia aquifer and two wells in the Upper Patapsco aquifer in the vicinity of Naval Air Station Patuxent River and Webster Outlying Field. Groundwater samples were analyzed for basic chemistry (field parameters, major ions, and nutrients) as well as several waterquality issues of concern including the occurrence of arsenic and tungsten, and saltwater intrusion.

The results of the 2008 groundwater-quality sampling indicate that the overall quality of groundwater in the Aquia aquifer has not changed since 1943; data are too limited to determine if groundwater quality has changed in the Upper Patapsco aquifer. At one well in the Aquia aquifer, the arsenic concentration exceeded the U.S. Environmental Protection Agency standard for drinking water. Arsenic was not detected in samples from the Upper Patapsco aquifer. Tungsten concentrations were detected at low concentrations near the laboratory reporting level in all eight samples. There was no evidence of saltwater intrusion in any of the wells.

\section{Introduction}

Development near the Naval Air Station Patuxent River (NAS Patuxent River) has resulted in rapid population growth in southern Maryland. This rapid population growth is a concern to State and County water managers, private citizens, and air station officials because of its impact on water supplies, as water withdrawals from groundwater have increased to meet increasing water demands. Increases in groundwater pumpage can lead to saltwater intrusion into freshwater aquifers from saline groundwater or from brackish water or seawater in coastal settings such as at NAS Patuxent River. Since 1998, the U.S. Geological Survey (USGS), in cooperation with the NAS Patuxent River, has been investigating the water resources of the Piney Point-Nanjemoy, Aquia, and more recently, the Upper Patapsco aquifers in the vicinity of the air station and Webster Outlying Field (WOLF) to understand the effects of water-use practices at NAS Patuxent River and WOLF on the water resources of the surrounding area.

In addition to saltwater intrusion, the NAS Patuxent River groundwater-quality assessment was designed to evaluate the occurrence and distribution of arsenic and tungsten. Arsenic is an element that occurs naturally in the environment and is present in the Aquia aquifer (Drummond and Bolton, 2010). Arsenic also is a known human carcinogen (Agency for Toxic Substances and Disease Registry, 2007). The U.S. Environmental Protection Agency (USEPA) regulates arsenic concentrations in public drinking water and has set an enforceable Maximum Contaminant Level (MCL) of $10 \mu \mathrm{g} / \mathrm{L}$ 
(micrograms per liter) to protect public health and safety (U.S. Environmental Protection Agency, 2011). Tungsten is a metal that was used in "green" ammunitions by the military as an alternative to lead or depleted uranium. Tungsten has been detected in the soil and groundwater at firing ranges at other military facilities that have used tungsten ammunitions (U.S. Environmental Protection Agency, 2009). There is no Federal drinking-water standard established for tungsten; however, there is growing concern about the potential health effects of exposure to tungsten (Agency for Toxic Substances and Disease Registry, 2005). Tungsten ammunitions were not used at NAS Patuxent River; however, water resource managers wanted samples analyzed for tungsten as a preemptive measure for possible future requirements for military facilities to test for tungsten in groundwater.

\section{Purpose and Scope}

The purpose of this report is to describe the occurrence and distribution of selected constituents in samples collected from eight wells screened in the Aquia and Upper Patapsco aquifers in July 2008 at NAS Patuxent River and WOLF. The report describes the general water chemistry of the aquifers, compares chemistry in samples collected in 1999-2001 and 2008, describes the occurrence of arsenic and tungsten, and documents the status of saltwater intrusion.

\section{Description of Study Area and Well Numbering System}

NAS Patuxent River is in St. Mary's County in southern Maryland, near the convergence of the Patuxent River and Chesapeake Bay. WOLF is south of NAS Patuxent River, on the St. Mary's River near St. Inigoes, Maryland (fig.1). NAS Patuxent River and WOLF encompass approximately 8,850 acres (U.S. Navy, 2010). In 2010, NAS Patuxent River was the largest employer in St. Mary's County, with a workforce of approximately 17,000 personnel (U.S. Navy, 2010).

The Aquia aquifer (table 1) is a deep, confined aquifer consisting of greenish-black quartz sand, glauconite, and lenses of clay and shell beds of the Aquia Formation (Chapelle and Drummond, 1983). The elevation of the top of the Aquia aquifer is approximately $-450 \mathrm{ft}$ (feet) relative to the North American Vertical Datum of 1988 (NAVD 88) beneath NAS Patuxent River and WOLF (Klohe and Feehley, 2001), and the thickness of the aquifer decreases from about 100 to $145 \mathrm{ft}$ at NAS Patuxent River to about $50 \mathrm{ft}$ at WOLF (Klohe and Kay, 2007).

The Upper Patapsco aquifer is a deep, confined aquifer which underlies the Aquia aquifer and consists of sand units interbedded with silt and clay units and is part of the Patapsco Formation of the Potomac Group (Klohe and Kay, 2007). The elevation of the top of the Upper Patapsco aquifer is approximately $-660 \mathrm{ft}$ NAVD 88 at well SM Df 100 (fig. 2) at NAS
Patuxent River and approximately -625 ft NAVD 88 at WOLF, and the thickness of the aquifer is approximately 200 to $240 \mathrm{ft}$ at NAS Patuxent River and WOLF.

The locations of wells discussed in this report are shown in figure 2. Well-construction data are presented in table 2. In this report, wells are listed by their USGS identification number. For example, well SM Dg 14 is a well located in St. Mary's County, indicated by the first two letters "SM;" in the 5-minute quadrangle (LaMotte, 2010) "Dg," indicated by the second two letters; and is the 14th well mapped in the quadrangle, indicated by the last two numbers "14." The 5-minute quadrangles are designated by upper-case letters from north to south (A through F in St. Mary's County), and lower-case letters from west to east (a through h in St. Mary's County).

\section{Previous Investigations}

The water quality of the confined aquifers of southern Maryland, which includes St. Mary's and Calvert Counties, has been discussed in reports by both the USGS and the Maryland Geological Survey (MGS). One of the earliest reports describing water quality at NAS Patuxent River was a report by Bennett (1944) that provided water chemistry for four wells at the air station. The next report addressing water quality was by Chapelle and Drummond (1983). That report described the chemical evolution of groundwater in the Aquia and Piney Point-Nanjemoy aquifers in southern Maryland, including the NAS Patuxent River and WOLF areas. The groundwater type, or major ion chemistry, was found to change along the direction of flow. For example, the Aquia aquifer is generally calcium- and magnesium-bicarbonate type water with a $\mathrm{pH}$ of 6.5 to 7.5 near the outcrop/subcrop area, and changes downgradient to a sodium-bicarbonate type water with a relatively high $\mathrm{pH}$, ranging from 7.5 to 8.5 (Chapelle and Drummond, 1983).

More recently, Klohe and Feehley (2001) described groundwater quality in the Piney Point-Nanjemoy and Aquia aquifers at NAS Patuxent River and WOLF. They found that groundwater in the Piney Point-Nanjemoy aquifer is of the calcium-magnesium-sodium-bicarbonate type, whereas groundwater in the Aquia aquifer is of the sodium-bicarbonate type. Klohe and Feehley (2001) compared historical data from groundwater samples collected from the Aquia aquifer in the 1940s through the early 1960s (Chapelle and Drummond, 1983) to samples collected in 1999, and found that the concentrations of major constituents had not changed appreciably in either the Piney Point-Nanjemoy aquifer or the Aquia aquifer. Klohe and Feehley (2001) also found no evidence of saltwater intrusion in either the Piney Point-Nanjemoy or the Aquia aquifer at NAS Patuxent River. At WOLF, the levels of some constituents in the Aquia aquifer were still within the range of values expected for freshwater, but were slightly higher than levels in the Aquia aquifer at NAS Patuxent River, which may indicate the very early stages of saltwater intrusion at WOLF (Klohe and Feehley, 2001). 


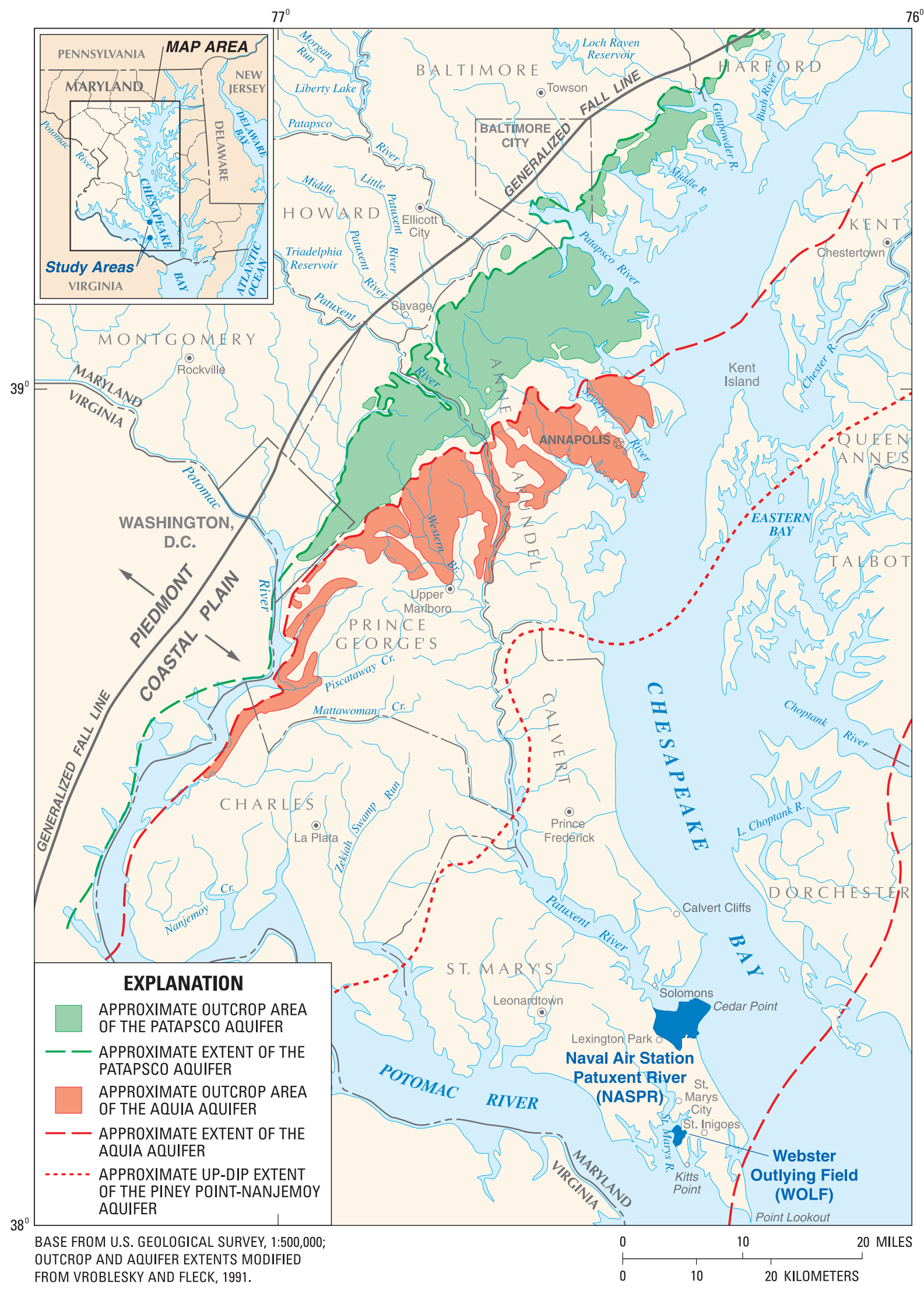

Figure 1. Location of Naval Air Station Patuxent River, St. Mary's County, Maryland (modified from Klohe and Kay, 2007, fig. 1). 
Table 1. Hydrologic and corresponding geologic units at Naval Air Station Patuxent River and Webster Outlying Field, St. Mary's County, Maryland (modified from Klohe and Kay, 2007).

\begin{tabular}{|c|c|c|c|}
\hline System & Series & Geologic unit & Hydrologic unit \\
\hline Quaternary & Holocene to Pleistocene & Surficial units & Surficial aquifer \\
\hline \multirow{9}{*}{ Tertiary } & Pliocene & (undifferentiated) & \\
\hline & \multirow{2}{*}{ Miocene } & Chesapeake Group & Upper confining unit \\
\hline & & (undivided) & \multirow{3}{*}{ Piney Point-Nanjemoy aquifer } \\
\hline & Oligocene (?) & unnamed Oligocene (?) Miocene (?) beds & \\
\hline & \multirow[b]{2}{*}{ Eocene } & Piney Point Formation & \\
\hline & & Nanjemoy Formation & \multirow[b]{2}{*}{ Middle confining unit } \\
\hline & \multirow{3}{*}{ Paleocene } & Marlboro Clay & \\
\hline & & Aquia Formation & Aquia aquifer \\
\hline & & Brightseat Formation & Lower confining unit \\
\hline \multirow{3}{*}{ Cretaceous } & \multirow{3}{*}{ Lower Cretaceous } & \multirow{3}{*}{$\begin{array}{l}\text { Patapsco Formation } \\
\text { of the Potomac Group }\end{array}$} & Upper Patapsco aquifer \\
\hline & & & Confining unit \\
\hline & & & Undifferentiated aquifers and confining units \\
\hline
\end{tabular}

Klohe and Kay (2007) described water quality for two wells screened in the Upper Patapsco aquifer. On the basis of samples collected from the two wells, they found that the groundwater in the Upper Patapsco aquifer is sodium-bicarbonate type. Groundwater sampled as part of their study met all Federal drinking-water standards (for constituents that were analyzed for which Federal drinking-water standards have been established).

\section{Sample Collection, Analysis, and Quality Control}

In July 2008, the USGS collected groundwater-quality samples from eight wells at NAS Patuxent River and WOLF. Field parameters, including temperature, $\mathrm{pH}$, dissolved oxygen, alkalinity, and specific conductance, were measured at the wells at the time of sample collection. Samples were processed in the field and shipped to the analyzing laboratory.

\section{Sample Collection and Analysis}

Groundwater samples were collected by USGS personnel from five wells screened in the Aquia aquifer and one well screened in the Upper Patapsco aquifer at NAS Patuxent River (fig. 2). Samples also were collected from one well screened in the Aquia aquifer and one well screened in the Upper Patapsco aquifer at WOLF (fig. 2). All of the wells sampled were production wells that supply water for various uses at the air station and all had some type of chlorine treatment. All samples were collected from spigots before treatment or storage. Water-quality samples were collected and processed according to USGS protocols (U.S. Geological Survey, variously dated) and shipped to the USGS National Water Quality Laboratory (NWQL) in Denver, Colorado for analysis of major ions, selected minor ions, nutrients, arsenic, and tungsten. Data from these sampling events are reported in accordance with NWQL reporting protocols.

The NWQL has established reporting conventions for low concentration water-quality data that are based upon two brackets for constituent concentration: the long-term method detection level (LT-MDL) and the laboratory reporting level (LRL). These markers were designed to reduce the occurrence of false positive and false negative detection errors to less than or equal to 1 percent. Concentrations reported as less than $(<)$ a given value can be assumed to be less than the LRL for that constituent (Oblinger Childress and others, 1999). Concentrations are typically coded as estimated (E) because either the constituent measured has a concentration which is below the LRL but above the LT-MDL or the constituent concentration is measured outside the calibration range (Oblinger Childress and others, 1999). In the case of carbonate and bicarbonate, if there is discrepancy between the measured and theoretical endpoints for carbonate as determined via alkalinity titration, both carbonate and bicarbonate concentrations must be reported as estimated (U.S. Geological Survey, 2007). Constituents reported as estimated and an explanation for each case is given in table 3, and corresponding LRL and LT-MDL values are given where applicable. 


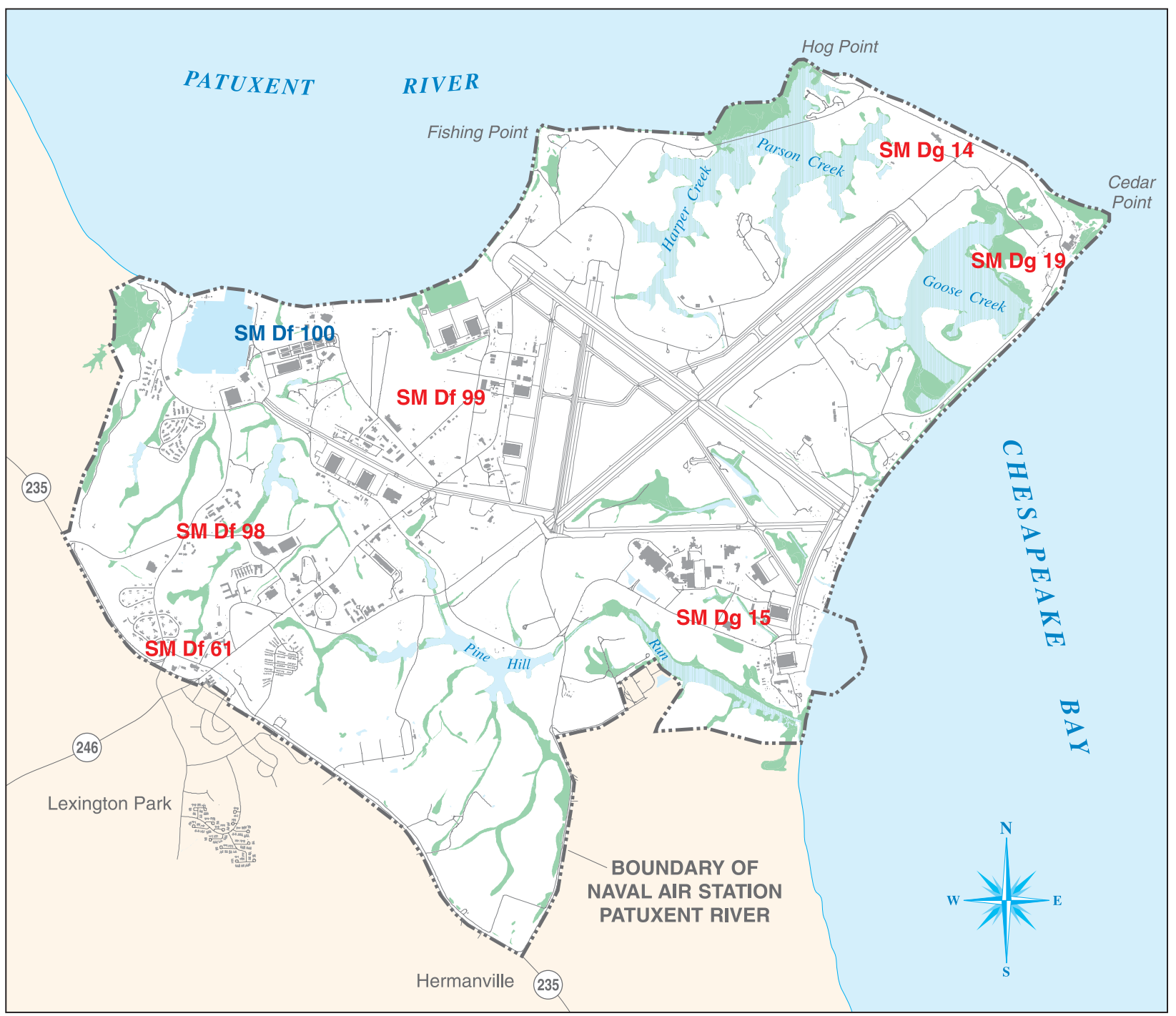

BASE PROVIDED BY NAVAL AIR STATION PATUXENT RIVER

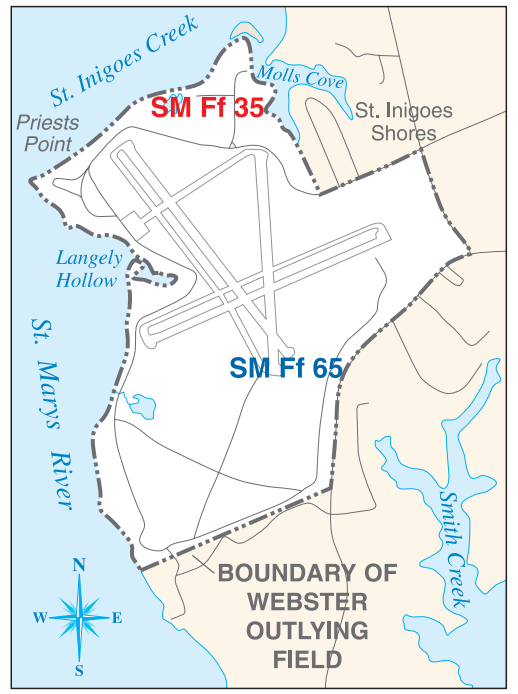

\title{
EXPLANATION
}

\author{
WETLAND \\ SM Ff 35 AQUIA AQUIFER WELL IDENTIFIER \\ SM Df 100 UPPER PATAPSCO AQUIFER WELL IDENTIFIER
}

Figure 2. Selected well locations at Naval Air Station Patuxent River and Webster Outlying Field, St. Mary's County, Maryland (modified from Klohe and Kay, 2007). 
Table 2. Records for selected wells at Naval Air Station Patuxent River and Webster Outlying Field, St. Mary's County, Maryland.

[USGS, U.S. Geological Survey; NAVD 88, North American Vertical Datum of 1988]

\begin{tabular}{|c|c|c|c|c|c|c|c|c|}
\hline $\begin{array}{c}\text { USGS } \\
\text { well } \\
\text { number }\end{array}$ & $\begin{array}{c}\text { Altitude } \\
\text { of land } \\
\text { surface } \\
\text { (feet } \\
\text { above } \\
\text { NAVD 88) }\end{array}$ & Aquifer & $\begin{array}{l}\text { Depth of } \\
\text { well } \\
\text { (feet } \\
\text { below } \\
\text { land } \\
\text { surface) }\end{array}$ & $\begin{array}{c}\text { Well } \\
\text { diameter } \\
\text { upper- } \\
\text { lower } \\
\text { (inches) }\end{array}$ & $\begin{array}{c}\text { Screen } \\
\text { position } \\
\text { (feet below } \\
\text { land } \\
\text { surface) }\end{array}$ & $\begin{array}{c}\text { Date of } \\
\text { construction }\end{array}$ & $\begin{array}{c}\text { State of } \\
\text { Maryland } \\
\text { well permit } \\
\text { number }\end{array}$ & Driller \\
\hline SM Df 98 & 80 & Aquia & 575 & $8-6$ & $525-575$ & $12 / 15 / 1996$ & SM-94-0410 & A.C. Schultes of Maryland \\
\hline SM Df 99 & 44 & Aquia & 600 & $16-8$ & $490-600$ & $11 / 8 / 1994$ & SM-92-0642 & Vans Construction Co. \\
\hline SM Df 100 & 20 & $\begin{array}{l}\text { Upper } \\
\text { Patapsco }\end{array}$ & 910 & $10-8$ & $\begin{array}{l}706-716, \\
744-754, \\
835-860, \\
882-892, \\
900-905\end{array}$ & $8 / 4 / 2000$ & SM-94-3113 & A.C. Schultes of Maryland \\
\hline SM Dg 14 & 18 & Aquia & 542 & $8-6$ & $490-540$ & $4 / 22 / 1994$ & SM-92-0370 & A.C. Schultes of Maryland \\
\hline SM Dg 15 & 20 & Aquia & 500 & $8-5$ & $450-500$ & $12 / 17 / 1993$ & SM-92-0570 & Patuxent Pump and Well Co. \\
\hline SM Dg 19 & 9 & Aquia & 532 & $12-8$ & $480-510$ & 6/23/1988 & SM-81-3345 & Syndor Pump and Well Co. \\
\hline SM Ff 35 & 4 & Aquia & 537 & $8-4$ & $487-537$ & 8/8/1975 & SM-73-1496 & A.C. Schultes of Maryland \\
\hline SM Ff 65 & 9 & $\begin{array}{l}\text { Upper } \\
\text { Patapsco }\end{array}$ & 884 & $10-8$ & $\begin{array}{l}635-640, \\
648-658, \\
689--694, \\
782-792, \\
846-856, \\
864-874\end{array}$ & $8 / 10 / 2001$ & SM-94-3700 & A.C. Schultes of Maryland \\
\hline
\end{tabular}

\section{Quality Control}

Quality-control samples were collected in addition to the environmental samples to estimate the magnitude of the bias and variability that results from sample collection, processing, and laboratory analysis. A field blank was collected at well SM Ff 65 using inorganic blank water certified by the USGS laboratory to test for potential sources of contamination of environmental samples during collection, shipping, or laboratory analysis. Replicate samples were collected at wells SM Df 98 and SM Df 100 to measure the variability in the waterquality data.

Quality-control results are presented along with environmental sample results in table 4. Field-blank data were reported as less than the LRL for all laboratory-measured constituents except calcium. Calcium had an estimated concentration of $0.03 \mathrm{mg} / \mathrm{L}$ (milligrams per liter), below the LRL of $0.04 \mathrm{mg} / \mathrm{L}$, and was not a contamination concern because all environmental concentrations exceeded the reporting level by two orders of magnitude. The percent relative standard deviation (percent RSD) was calculated from the replicate data using the following equation:

$$
\text { Percent RSD }=100\left(\frac{\sqrt{(x 1-x 2)^{2} / 2}}{(x 1+x 2) / 2}\right)
$$

where

$$
\begin{aligned}
& x 1=\text { the concentration of the environmental } \\
& \text { groundwater sample, and } \\
& x 2=\text { the concentration of the replicate sample. }
\end{aligned}
$$

The percent RSD was less than 4 percent for all laboratory-measured constituents except iodide (percent RSD = 7.4) and barium (percent RSD = 12.9) for well SM Df 98, and calcium (percent RSD = 12.9) and iron (percent RSD = 6.1) for well SM Df 100. For some of these constituents, the precision of reporting and the low concentration of the parameter resulted in a large calculated variability despite small differences in constituent concentration between environmental and replicate samples. Calculating percent RSDs near the reporting level where reporting intervals, the smallest increment by which reported values change, represent a significant proportion of the reported concentration can result in misleadingly high percent RSDs.

The median of the percent RSDs for all laboratory-measured constituents was 0.6 percent, indicating that variability in the water-quality data are minimal, with the exception of data for iodide, barium, calcium, and iron. The percent RSD was less than 1.0 percent when field-measured values and laboratory-measured values for $\mathrm{pH}$ and specific conductance were compared. 
Table 3. Water-quality parameters with concentrations reported as estimated (E), justification for data qualifier, and long-term method detection levels (LT-MDLs) and laboratory reporting levels (LRLs) that bracket the estimated concentrations where applicable.

[mg/L, milligrams per liter; $\mu \mathrm{g} / \mathrm{L}$, micrograms per liter; N/A, not applicable]

\begin{tabular}{|c|c|c|c|}
\hline $\begin{array}{l}\text { Constituents with } \\
\text { values reported as } \\
\text { “E”, estimated }\end{array}$ & LT-MDL 2008' & LRL 20081 & Reason for reporting value as estimated \\
\hline Arsenic & $0.03 \mu \mathrm{g} / \mathrm{L}$ & $0.06 \mu \mathrm{g} / \mathrm{L}$ & Concentration falls between LT-MDL and LRL. ${ }^{2}$ \\
\hline Bicarbonate (field) & N/A & N/A & Alkalinity titration endpoint for carbonate does not match theoretical. ${ }^{3}$ \\
\hline Bromide & $0.01 \mathrm{mg} / \mathrm{L}$ & $0.02 \mathrm{mg} / \mathrm{L}$ & Concentration falls between LT-MDL and LRL. \\
\hline Calcium & $0.02 \mathrm{mg} / \mathrm{L}$ & $0.04 \mathrm{mg} / \mathrm{L}$ & Concentration falls between LT-MDL and LRL. \\
\hline Iron & $4 \mu \mathrm{g} / \mathrm{L}$ & $8 \mu \mathrm{g} / \mathrm{L}$ & Concentration falls between LT-MDL and LRL. \\
\hline Manganese & $0.2 \mu \mathrm{g} / \mathrm{L}$ & $0.4 \mu \mathrm{g} / \mathrm{L}$ & Concentration falls between LT-MDL and LRL. \\
\hline Nitrate + nitrite & $0.02 \mathrm{mg} / \mathrm{L}$ & $0.04 \mathrm{mg} / \mathrm{L}$ & Concentration falls between LT-MDL and LRL. \\
\hline Total Nitrogen & $0.03 \mathrm{mg} / \mathrm{L}$ & $0.06 \mathrm{mg} / \mathrm{L}$ & Concentration falls between LT-MDL and LRL. \\
\hline
\end{tabular}

\section{Groundwater Quality and Occurrence and Distribution of Selected Constituents}

Groundwater samples were collected from wells screened in the Aquia and Upper Patapsco aquifers to describe the general water chemistry of these aquifers. The data were compared with data presented in previous USGS and MGS investigations (Bennett, 1944; Chapelle and Drummond, 1983; Klohe and Feehley, 2001; Klohe and Kay, 2007) to determine if water quality had changed over time in the aquifers. Sample data also were used to describe the occurrence and distribution of arsenic and tungsten, and the status of saltwater intrusion at NAS Patuxent River and WOLF. Results of the 2008 groundwater-sample analyses are provided in table 4.

\section{Groundwater-Quality Characterization of the Aquia and Upper Patapsco Aquifers}

Of the six wells in the Aquia aquifer from which groundwater samples were collected, the principal cations and anions in groundwater were sodium and bicarbonate, respectively (table 4). For the five Aquia aquifer wells at NAS Patuxent River, the $\mathrm{pH}$ ranged from 8.7 to 8.9 , specific conductance ranged from 310 to $332 \mu \mathrm{S} / \mathrm{cm}$ (microsiemens per centimeter at 25 degrees Celsius), and alkalinity ranged from 150 to 164 $\mathrm{mg} / \mathrm{L}$ (as calcium carbonate). Total nitrogen concentrations were low, ranging from 0.14 to $0.19 \mathrm{mg} / \mathrm{L}$, and only well SM Df 98 had a detectable concentration of nitrate plus nitrite with an estimated value of $0.23 \mathrm{mg} / \mathrm{L}$ (as N). The median concentrations of major cations and anions were $2.95 \mathrm{mg} / \mathrm{L}$ of calcium, $1.32 \mathrm{mg} / \mathrm{L}$ of magnesium, $6.99 \mathrm{mg} / \mathrm{L}$ of potassium, 70.8 $\mathrm{mg} / \mathrm{L}$ of sodium, $1.70 \mathrm{mg} / \mathrm{L}$ of chloride, $0.54 \mathrm{mg} / \mathrm{L}$ of fluoride, $11.2 \mathrm{mg} / \mathrm{L}$ of silica, and $5.70 \mathrm{mg} / \mathrm{L}$ of sulfate.

At WOLF, the water sampled from well SM Ff 35 (screened in the Aquia aquifer) had a different chemistry than the chemistry in samples from the NAS Patuxent River wells. At well SM Ff 35, the Aquia aquifer $\mathrm{pH}$ was 8.6, specific conductance was $580 \mu \mathrm{S} / \mathrm{cm}$, and alkalinity was $304 \mathrm{mg} / \mathrm{L}$ (as calcium carbonate). The total nitrogen concentration was 0.17 $\mathrm{mg} / \mathrm{L}$, and the nitrite concentration was $0.003 \mathrm{mg} / \mathrm{L}$ (as N). The major cation and anion concentrations were $2.77 \mathrm{mg} / \mathrm{L}$ of calcium, $1.46 \mathrm{mg} / \mathrm{L}$ of magnesium, $7.67 \mathrm{mg} / \mathrm{L}$ of potassium, $125 \mathrm{mg} / \mathrm{L}$ of sodium, $4.08 \mathrm{mg} / \mathrm{L}$ of chloride, $1.22 \mathrm{mg} / \mathrm{L}$ of fluoride, $11.1 \mathrm{mg} / \mathrm{L}$ of silica, and $12.6 \mathrm{mg} / \mathrm{L}$ of sulfate. The differences in water chemistry in the Aquia aquifer between NAS Patuxent River and WOLF may be due to chemical reactions between the groundwater and the aquifer matrix as the water moves downgradient from NAS Patuxent River toward WOLF (Chapelle and Drummond, 1983). 


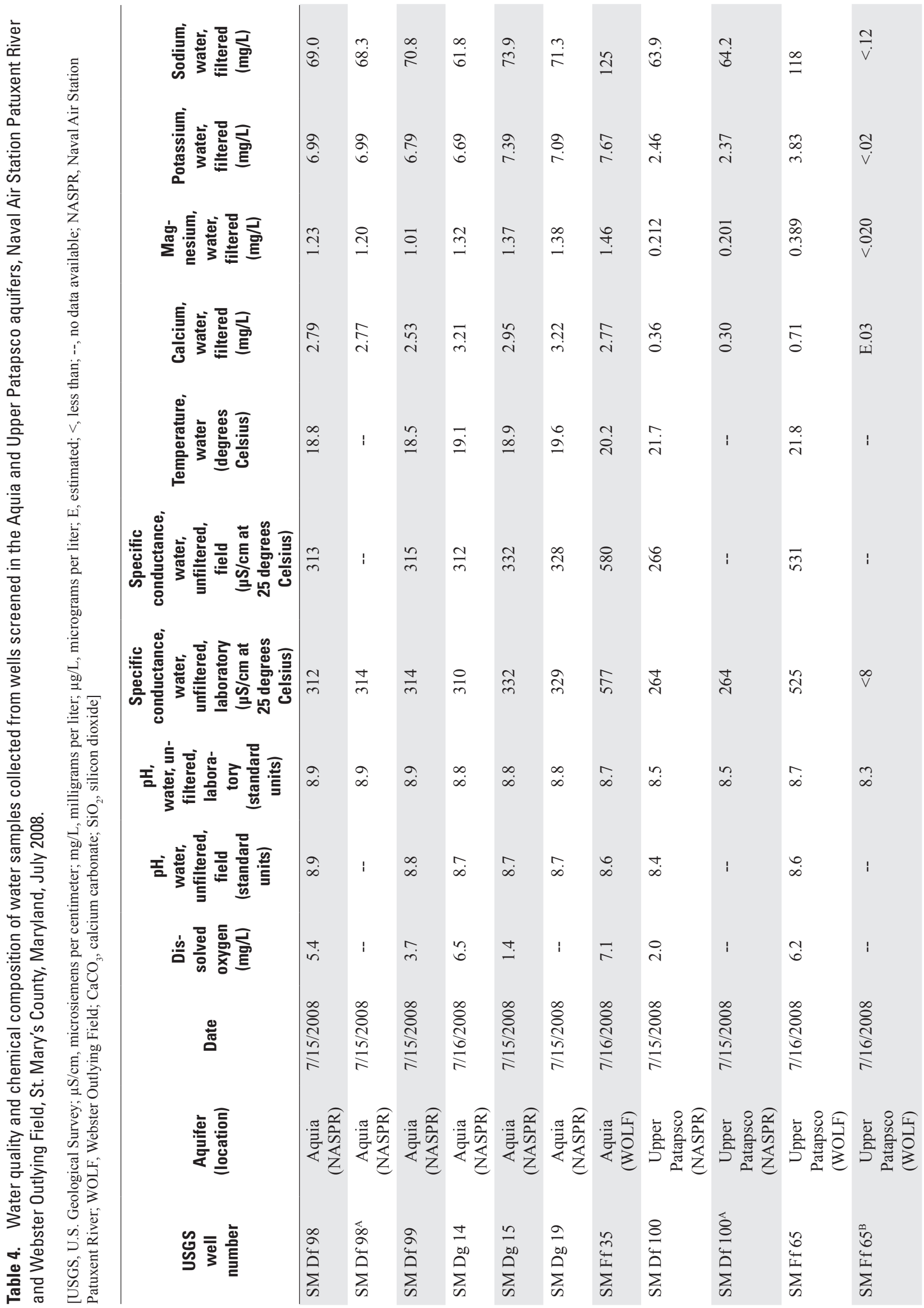




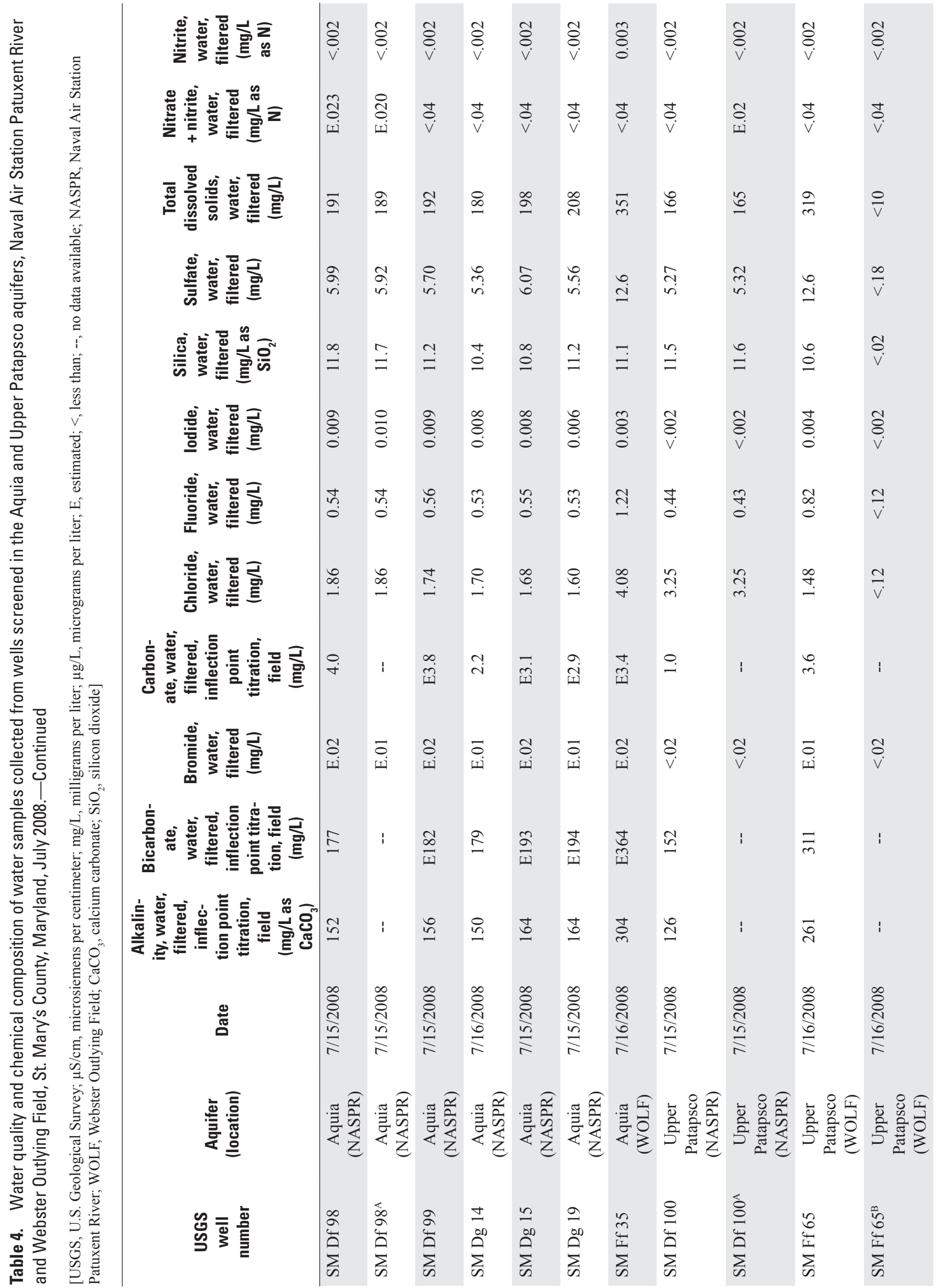




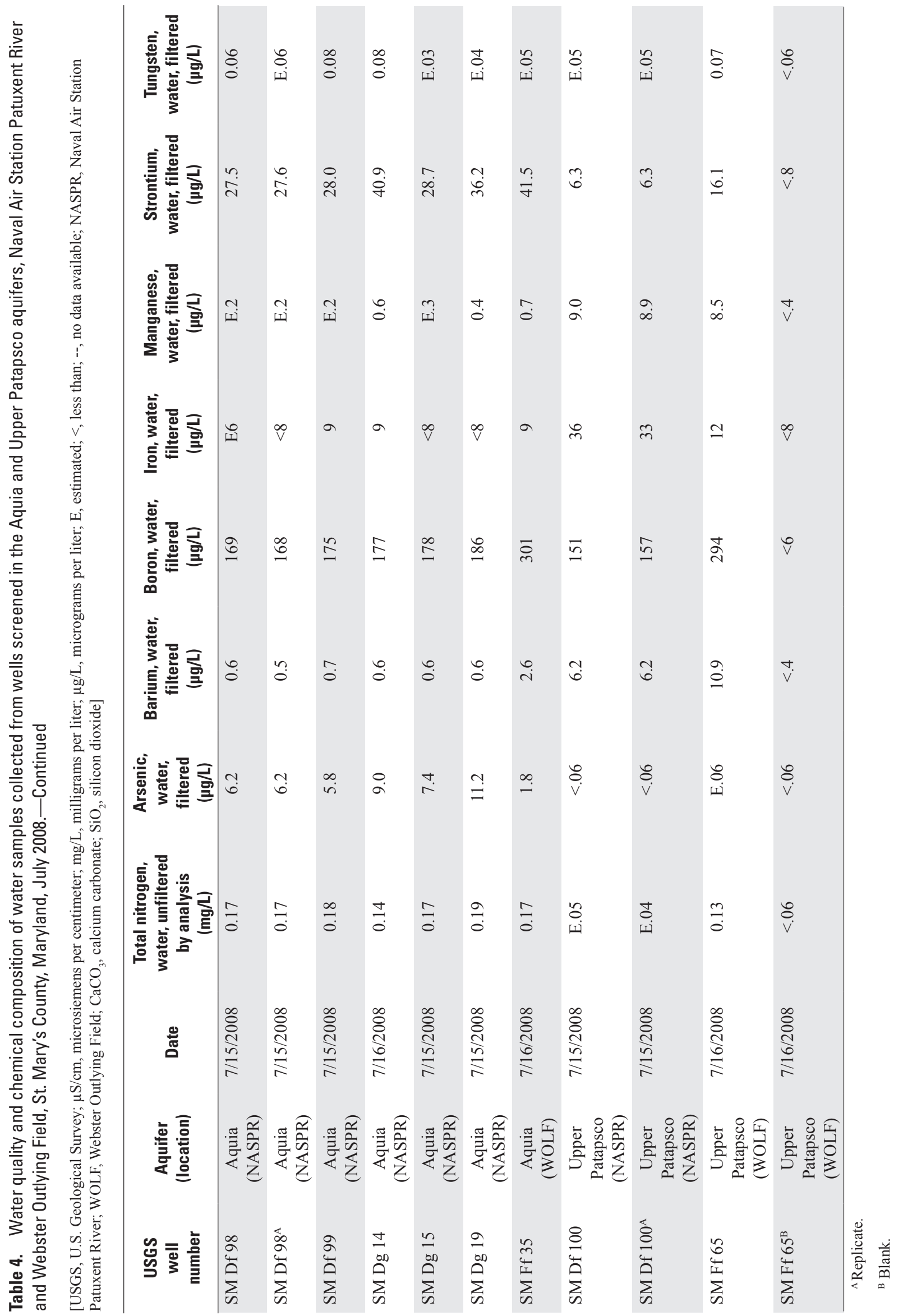


Water samples were collected from well SM Df 100, screened in the Upper Patapsco aquifer at NAS Patuxent River, and well SM Ff 65, screened in the Upper Patapsco aquifer at WOLF. As was the case with the Aquia aquifer samples, the principal cations and anions in the Upper Patapsco aquifer samples were sodium and bicarbonate, respectively. The water sample from the Upper Patapsco aquifer at WOLF typically had major ion concentrations that were approximately two times greater than the water sample from the Upper Patapsco aquifer at NAS Patuxent River (table 4). For example, the concentration of calcium was $0.36 \mathrm{mg} / \mathrm{L}$ at NAS Patuxent River and $0.71 \mathrm{mg} / \mathrm{L}$ at WOLF, the concentration of fluoride was $0.44 \mathrm{mg} / \mathrm{L}$ at NAS Patuxent River and $0.82 \mathrm{mg} / \mathrm{L}$ at WOLF, and the concentration of sodium was $63.9 \mathrm{mg} / \mathrm{L}$ at NAS Patuxent River and $118 \mathrm{mg} / \mathrm{L}$ at WOLF. The ratios of these constituents however, are similar at NAS Patuxent River and WOLF. For example, the ratio of calcium to fluoride is 0.82 at NAS Patuxent River, and 0.87 at WOLF. Characterization of the water quality of the Upper Patapsco aquifer is limited due to the small dataset.

\section{Comparison of Groundwater Quality in the Aquia and Upper Patapsco Aquifers, 1943-2008}

Data from six Aquia aquifer wells and two Upper Patapsco aquifer wells sampled in 1999-2001 and resampled in 2008 were compared by bar chart and Piper diagram analysis to determine whether changes in water quality had occurred. Results from sampling of the Aquia aquifer were also compared with historical data presented in Klohe and Feehley (2001).

Specific conductance and concentrations of major ions in selected water samples collected from the Aquia and Upper Patapsco aquifers at NAS Patuxent River and WOLF locations in 1999-2001 and 2008 are shown in figure $3(A-H)$. The data show little variation in water chemistry in both aquifers between 1999-2001 and 2008, with the exception of chloride. Chloride concentrations were higher in 2008 in wells SM Ff 35 and SM Df 100, however, a trend cannot be determined because there are only two data points for each well.

Major ions in the samples collected in 1999-2001 and 2008 were plotted on a Piper diagram for comparison among the water-quality datasets (fig. 4). Piper diagrams show the relative concentrations of major cations and anions as percentages of the total ionic concentration of the water (Piper, 1944). Waters with similar chemistry will plot in the same area on the diagram. The data from 1999-2001 and the data from 2008 for the Aquia aquifer all plot in the same location in the Piper diagram with the exception of one sample (from well SM Df 61, collected in 1999 only), indicating the water chemistry in the Aquia aquifer has not changed since 1999-2001 (fig. 4). The chemistry of the water at well SM Df 61 is similar to that of the Piney Point-Nanjemoy aquifer, possibly because (1) the well is screened in both aquifers, or (2) improper or faulty construction is allowing water from the Piney Point-Nanjemoy aquifer to leak into the well (Klohe and Feehley, 2001).

Though the data collected from the Upper Patapsco aquifer are too limited to draw conclusive assumptions about the historical continuity of groundwater quality, results from 1999-2001 and 2008 plot in the same location on the Piper diagram, indicating that water quality has been consistent with respect to these parameters.

Historical data from groundwater samples collected from the Aquia aquifer in the 1940s through the early 1960s (Chapelle and Drummond, 1983) were presented in Klohe and Feehley (2001). During this period from the 1940s through 2001, the water chemistry in groundwater samples from the Aquia aquifer has remained constant, thus it can be concluded that the water chemistry in the Aquia aquifer at NAS Patuxent River has not changed since the 1940s. This would be expected because deep confined aquifers such as the Aquia and Upper Patapsco aquifers are less susceptible to landsurface influences. Analysis of the Upper Patapsco aquifer was not included in the 2001 study, and thus no comparison of recent sampling with historical data is made here.

\section{Arsenic and Tungsten}

Groundwater samples were collected and analyzed for arsenic to verify the presence and concentration of arsenic in the water-supply wells, and to serve as a baseline for comparison with arsenic concentrations in samples collected in future studies.

Arsenic concentrations in groundwater sampled from the six wells in the Aquia aquifer ranged from $1.8 \mu \mathrm{g} / \mathrm{L}$ to 11.2 $\mu \mathrm{g} / \mathrm{L}$ (table 4). The two wells located near the confluence of the Patuxent River and Chesapeake Bay at NAS Patuxent River (SM Dg 14 and SM Dg 19) had the highest arsenic concentrations $-9 \mu \mathrm{g} / \mathrm{L}$ and $11.2 \mu \mathrm{g} / \mathrm{L}$, respectively. The arsenic concentration at well SM Dg 19 was greater than the arsenic MCL of $10 \mu \mathrm{g} / \mathrm{L}$. Arsenic concentrations in the two wells sampled in the Upper Patapsco aquifer were less than the MCL, and were less than or equal to the LRL (table 4).

Groundwater samples were collected and analyzed for tungsten to determine its occurrence in the water-supply wells at the air station. The LRL for tungsten was $0.06 \mu \mathrm{g} / \mathrm{L}$ for the period when the samples were collected and analyzed. Of the six wells where groundwater was sampled from the Aquia aquifer, tungsten concentrations in three wells were estimated. The tungsten concentrations in the Aquia aquifer samples ranged from E0 $0.03 \mu \mathrm{g} / \mathrm{L}$ to $0.08 \mu \mathrm{g} / \mathrm{L}$. The tungsten concentrations in the Upper Patapsco aquifer samples were E0.05 $\mu \mathrm{g} / \mathrm{L}$ (SM Df 100, NAS Patuxent River) and $0.07 \mu \mathrm{g} / \mathrm{L}$ (SM Ff 65, WOLF) (table 4). 

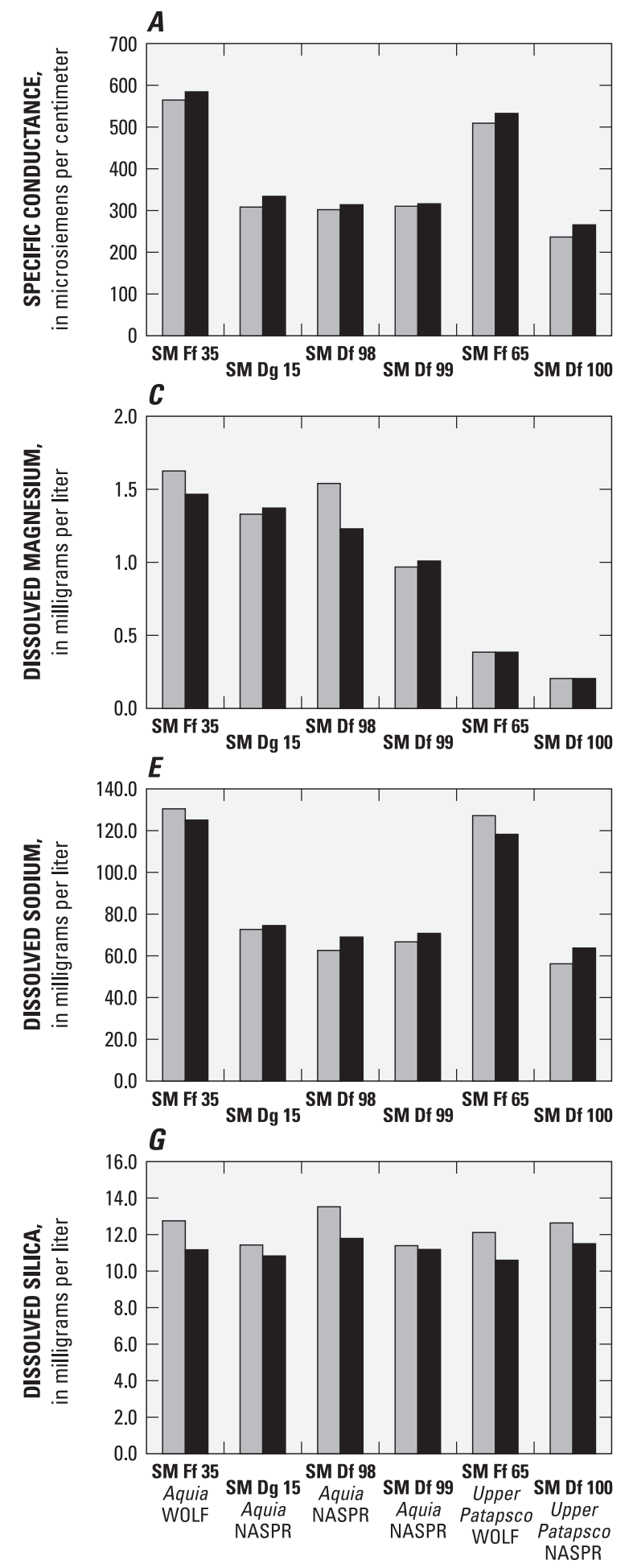
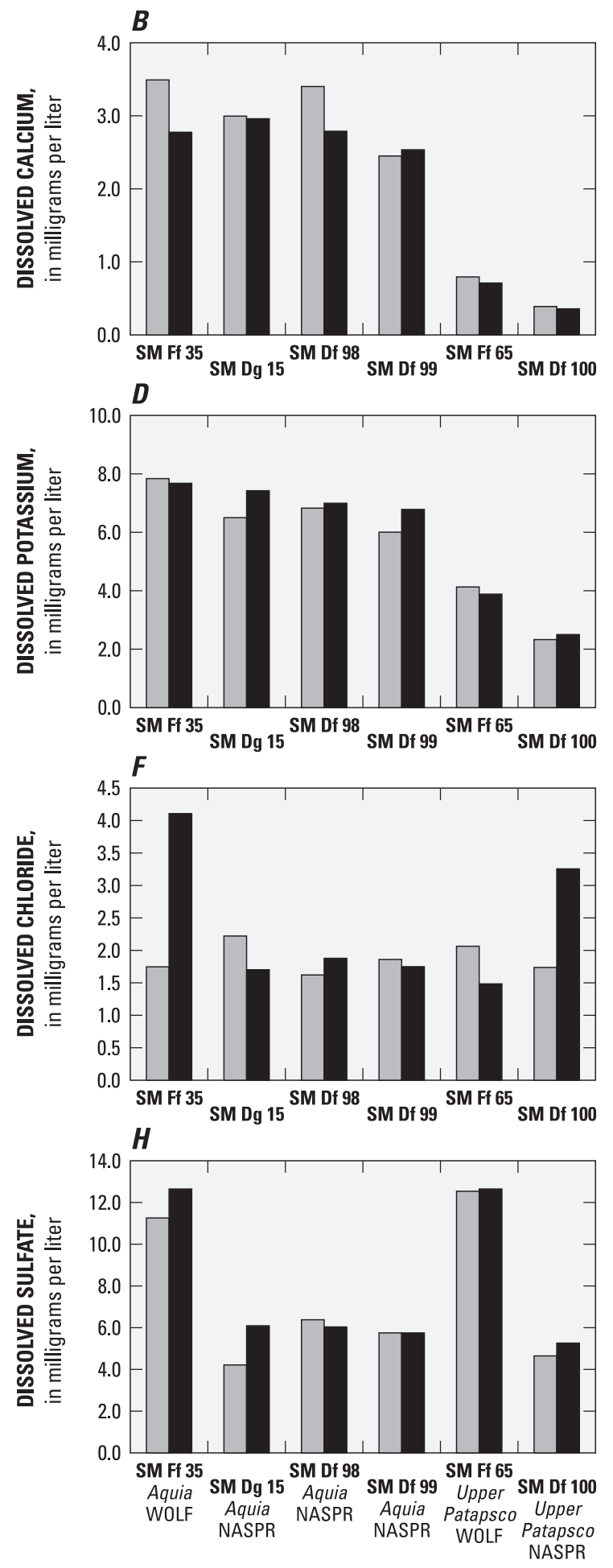

WELL NAME, AQUIFER, AND LOCATION

\title{
EXPLANATION
}

\author{
$\square$ 1999-2001 $\square 2008$
}

Figure 3. Comparisons of major ions in water samples collected from the Aquia and Upper Patapsco aquifers at the Naval Air Station Patuxent River (NASPR) and Webster Outlying Field (WOLF) locations in 1999-2001 and 2008. 


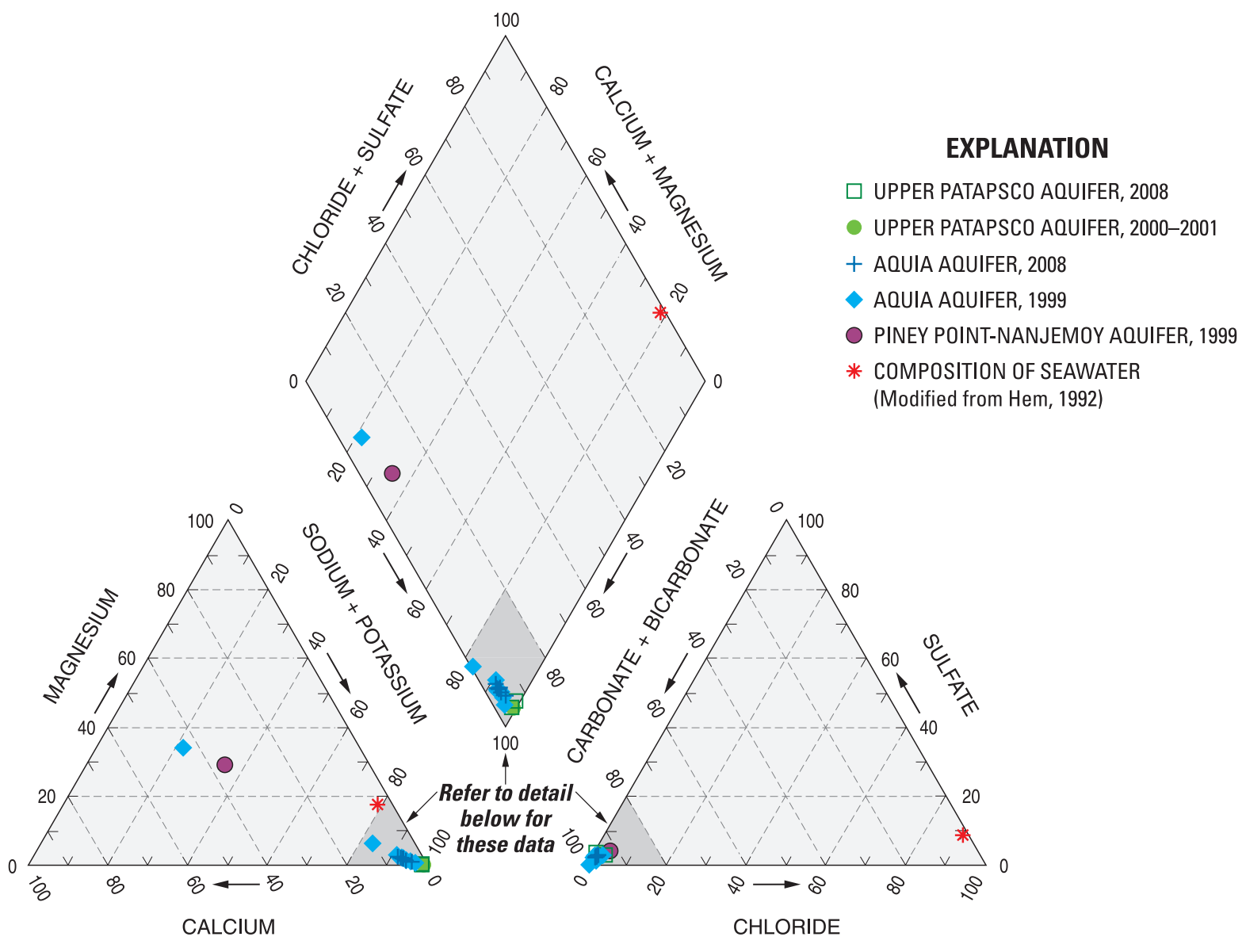

PERCENTAGE OF TOTAL MILLIEQUIVALENTS PER LITER

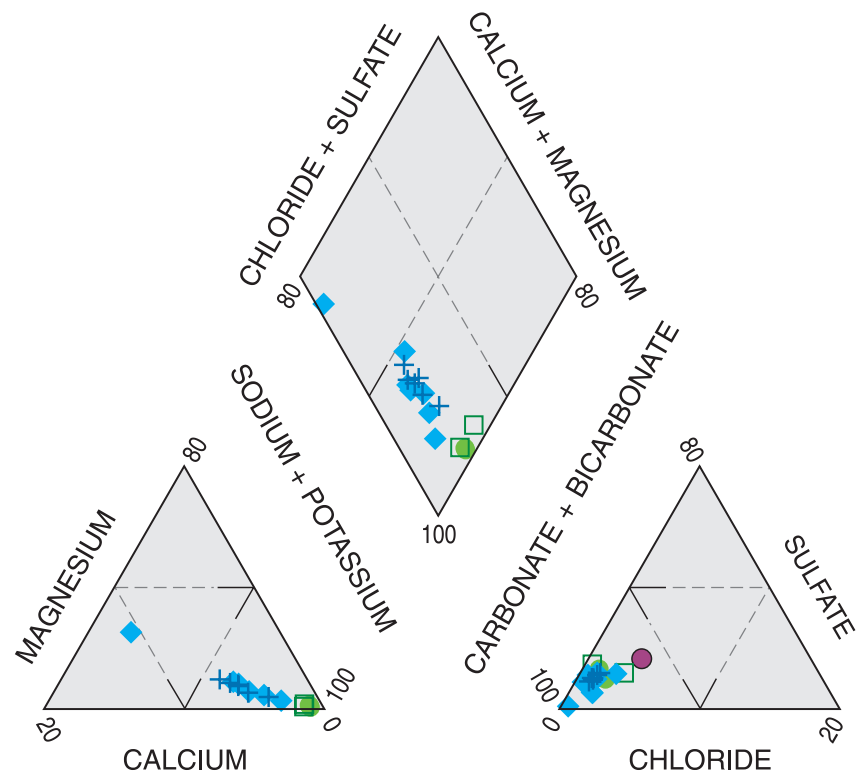

Figure 4. Comparison of the average chemical composition of seawater to the chemical composition of groundwater from selected wells at Naval Air Station Patuxent River and Webster Outlying Field, St. Mary's County, Maryland. 


\section{Saltwater Intrusion}

Freshwater aquifers in coastal areas are vulnerable to contamination by saltwater intrusion, which is the movement of saline water into freshwater aquifers. Pumping from groundwater wells is most often the cause of saltwater intrusion in coastal areas (Barlow, 2003), leading to the eventual abandonment of water-supply wells when concentrations of Federally regulated saltwater-related contaminants exceed drinking-water standards. Seawater from the ocean and estuaries is a major source of saltwater in coastal aquifers; however, entrapped fossil seawater, or connate water, can be another source of contamination. The possibility of saltwater intrusion into the aquifers at the air station is a concern because of their proximity to saline Patuxent River, Chesapeake Bay, and other estuaries. Increased demands for water supply for the air station and adjacent communities have the potential to induce saltwater intrusion into the freshwater aquifers. Six wells screened in the Aquia aquifer and two wells screened in the Upper Patapsco aquifer were sampled to detect the possible presence of saltwater.

A Piper diagram was used to compare water chemistry in the Aquia and Upper Patapsco aquifers to the average water chemistry of seawater. Data from the six Aquia aquifer wells sampled in 2008 plot in the same area on the diagram, showing that groundwater from these wells has similar water chemistry; however, the chemistry is different from average seawater chemistry (fig. 4). Data from the two Upper Patapsco aquifer wells sampled in 2008 plot in the same area of the Piper diagram as the Aquia aquifer samples, and also had different water chemistry than seawater.

Saltwater intrusion can be indicated by high total dissolved solids (TDS), high concentrations of chloride and sulfate, calcium to magnesium $(\mathrm{Ca}: \mathrm{Mg})$ ratios equal to 1.0 , sodium to chloride $(\mathrm{Na}: \mathrm{Cl})$ ratios equal to 2 , and chloride to bromide (Cl:Br) ratios equal to 287.5 (Klohe and Feehley, 2001). Saltwater is any water with TDS concentrations greater than $1,000 \mathrm{mg} / \mathrm{L}$, but seawater TDS concentrations average approximately $35,000 \mathrm{mg} / \mathrm{L}$ (Barlow, 2003). The median TDS for the six samples collected from the Aquia aquifer was 195 $\mathrm{mg} / \mathrm{L}$, with a maximum TDS of $351 \mathrm{mg} / \mathrm{L}$ at well SM Ff 35 located at WOLF (table 4). The two Upper Patapsco aquifer samples had TDS concentrations of $166 \mathrm{mg} / \mathrm{L}$ (well SM Df 100, NAS Patuxent River) and 319 mg/L (well SM Ff 65, WOLF) (table 4). In seawater, chloride concentrations are about $19,000 \mathrm{mg} / \mathrm{L}$ and sulfate concentrations are about 2,700 $\mathrm{mg} / \mathrm{L}$ (Hem, 1992). Chloride concentrations were less than 5 $\mathrm{mg} / \mathrm{L}$ and sulfate concentrations were less than $15 \mathrm{mg} / \mathrm{L}$ in the six Aquia aquifer wells and the two Upper Patapsco aquifer wells (tables 4 and 5). All indicators of saltwater intrusion were therefore well below seawater concentrations, indicating that saltwater intrusion has not occurred at NAS Patuxent River or WOLF.

Table 5. Comparison of average seawater and average connate water to groundwater samples collected in 2008 from the Aquia aquifer at Naval Air Station Patuxent River, and Webster Outlying Field, St. Mary's County, Maryland.

[TDS, total dissolved solids; Ca, calcium; $\mathrm{Mg}$, magnesium; $\mathrm{Na}$, sodium; $\mathrm{Cl}$, chloride; $\mathrm{Br}$, bromide; $\mathrm{mg} / \mathrm{L}$, milligrams per liter; $\mu \mathrm{g} / \mathrm{L}$, micrograms per liter; all ratios are reported in mg/L to mg/L; NASPR, Naval Air Station Patuxent River; WOLF, Webster Outlying Field]

\begin{tabular}{|c|c|c|c|c|}
\hline & Average seawater & Average connate water & $\begin{array}{c}\text { Aquia aquifer at } \\
\text { NASPR } \\
\text { (5 samples ) }\end{array}$ & $\begin{array}{c}\text { Aquia aquifer at } \\
\text { WOLF } \\
\text { (1 sample) }\end{array}$ \\
\hline TDS & 35,000 mg/L (Barlow, 2003) & & $180-208 \mathrm{mg} / \mathrm{L}$ & $351 \mathrm{mg} / \mathrm{L}$ \\
\hline Sulfate & 2,700 mg/L (Hem,1992; Drever, 1988) & & $5.36-6.07 \mathrm{mg} / \mathrm{L}$ & $12.6 \mathrm{mg} / \mathrm{L}$ \\
\hline Chloride & $19,000 \mathrm{mg} / \mathrm{L}(\mathrm{Hem}, 1992)$ & & $1.6-1.86 \mathrm{mg} / \mathrm{L}$ & $4.08 \mathrm{mg} / \mathrm{L}$ \\
\hline Ca:Mg & 1 (Piper and others, 1953) & & $2.2-2.5$ & 1.9 \\
\hline $\mathrm{Cl}: \mathrm{Br}$ & 287.5 (Stumm and Morgan, 1995) & & $84-186$ & 204 \\
\hline Barium & & 24-142 mg/L (Piper and others, 1953) & $0.6-0.7 \mu \mathrm{g} / \mathrm{L}$ & $2.6 \mu \mathrm{g} / \mathrm{L}$ \\
\hline Iodide & & 30-80 mg/L (Piper and others, 1953) & $0.006-0.009 \mathrm{mg} / \mathrm{L}$ & $0.003 \mathrm{mg} / \mathrm{L}$ \\
\hline
\end{tabular}




\section{Summary and Conclusions}

The Aquia and Upper Patapsco aquifers are water-supply sources for Naval Air Station Patuxent River (NAS Patuxent River) and Webster Outlying Field (WOLF) and the surrounding communities in southern Maryland, and there is concern about the effect of increasing water demands on the water quality in these aquifers. This report presents groundwater-quality data collected by the U.S. Geological Survey in July 2008 from eight wells screened in the Aquia and Upper Patapsco aquifers at NAS Patuxent River and WOLF.

Results of the groundwater sample analysis indicate that the principal cations and anions in groundwater samples collected from six wells screened in the Aquia aquifer were sodium and bicarbonate, respectively. The results also indicate that the principal cations and anions in groundwater samples collected from two wells screened in the Upper Patapsco aquifer were sodium and bicarbonate, respectively. Comparison of data from samples collected from 1943 to 1962, and samples collected in 1999 and 2008, indicates that water quality in the Aquia aquifer has not changed. Water-quality changes in the Upper Patapsco aquifer cannot be determined because of a limited dataset.

Arsenic, a naturally occurring element in the environment, was detected in all wells in the Aquia aquifer at concentrations ranging from $1.8 \mu \mathrm{g} / \mathrm{L}$ (micrograms per liter) to 11.2 $\mu \mathrm{g} / \mathrm{L}$. One well screened in the Aquia aquifer at NAS Patuxent River had an arsenic concentration greater than the U.S. Environmental Protection Agency's Maximum Contaminant Level of $10 \mu \mathrm{g} / \mathrm{L}$. Arsenic concentrations in the Upper Patapsco aquifer were equal to or less than the laboratory reporting level and were well below the U.S. Environmental Protection Agency Maximum Contaminant Level. Tungsten was detected in all eight samples, but at low concentrations (estimated 0.03 to $0.08 \mu \mathrm{g} / \mathrm{L}$ ). The average chemistry of seawater was compared to the chemistry of the eight samples collected from the Aquia aquifer or the Upper Patapsco aquifer, but no evidence of saltwater intrusion was observed.

\section{Acknowledgments}

The authors thank Michael Oliver and Denis Gonda at NAS Patuxent River for assisting with the study and providing logistical support to collect the samples. The authors also thank USGS personnel for the preparation, collection, and processing of the analytical samples, especially Noelle Stroik and Joseph Sullivan, and the many reviewers of this report for their helpful comments, especially Brandon Fleming, Jeffrey Chanat, Douglas Chambers, and Jennifer Stanton.

\section{References Cited}

Agency for Toxic Substances and Disease Registry (ATSDR), 2005, Toxicological profile for Tungsten: Atlanta, Georgia, U.S. Department of Health and Human Services, Public Health Service, accessed August 12, 2010 at URL http:// www.atsdr.cdc.gov/toxprofiles/tp186.pdf.

Agency for Toxic Substances and Disease Registry (ATSDR), 2007, Toxicological profile for Arsenic: Atlanta, Georgia, U.S. Department of Health and Human Services, Public Health Service, accessed August 12, 2010 at URL http:// www.atsdr.cdc.gov/ToxProfiles/tp2.pdf

Barlow, P.M., 2003, Ground water in freshwater-saltwater environments of the Atlantic Coast: U.S. Geological Survey Circular 1262, 113 p., available online at http://pubs.usgs. gov/circ/2003/circ1262/.

Bennett, R.R., 1944, Ground-water resources at the Naval establishments in the Solomons-Patuxent River area, Maryland: U.S. Geological Survey Open-File Report, 35 p.

Chapelle, F.H., and Drummond, D.D., 1983, Hydrogeology, digital simulation, and geochemistry of the Aquia and Piney Point-Nanjemoy aquifer system in southern Maryland: Maryland Geological Survey Report of Investigations No. 38, 100 p., 13 pls.

Drever, J.I, 1988, The geochemistry of natural waters: Englewood Cliffs, New Jersey, Prentice-Hall, 437 p.

Drummond, D.D., and Bolton, D.W., 2010, Arsenic in ground water in the Coastal Plain aquifers of Maryland: Maryland Geological Survey Report of Investigations No. 78, 72 p.

Faure, G., 1991, Principles and applications of inorganic chemistry: A comprehensive textbook for students: New York, Macmillan Publishing Company, 626 p.

Hem, J.D., 1992, Study and interpretation of the chemical characteristics of natural water ( $3 d$ ed.): U.S. Geological Survey Water-Supply Paper 2254, 263 p., available online at http://pubs.usgs.gov/wsp/wsp2254/.

Klohe, C.A., and Feehley, C.E., 2001, Hydrogeology and ground-water quality of the Piney Point-Nanjemoy and Aquia aquifers, Naval Air Station Patuxent River and Webster Outlying Field, St. Mary's County, Maryland: U.S. Geological Survey Water-Resources Investigations Report 01-4029, 51 p., available online at http://pubs.usgs.gov/wri/ wri01-4029/. 
Klohe, C.A., and Kay, R.T., 2007, Hydrogeology of the Piney Point-Nanjemoy, Aquia, and Upper Patapsco aquifers, Naval Air Station Patuxent River and Webster Outlying Field, St. Marys County, Maryland, 2000-06: U.S. Geological Survey Scientific Investigations Report 2006-5266, 26 p., available online at http://pubs.usgs.gov/ sir/2006/5266/.

LaMotte, A.E., 2010, Groundwater site identification indexes for Washington, D.C., Baltimore City, and the Counties of Maryland: U.S. Geological Survey Digital Data Series 576, available online at http://water.usgs.gov/GIS/metadata/ usgswrd/XML/mddc_indexes.xml.

Oblinger Childress, C.J., Foreman, W.T., Connor, B.F., and Maloney, T.J., 1999, New reporting procedures based on Long-Term Method Detection Levels and some considerations for interpretations of water-quality data provided by the U.S. Geological Survey National Water Quality Laboratory: U.S. Geological Survey Open-File Report 99-193, 19 p.

Piper, A.M., 1944, A graphic procedure in the geochemical interpretation of water analysis: American Geohysical Union Transactions, v. 25, p. 914-923.

Piper, A.M., Garrett, A.A., and others, 1953, Native and contaminated ground waters in the Long Beach-Santa Ana Area, California: U.S. Geological Survey Water-Supply Paper 1136, 320 p., 11 pls., available online at http://pubs. usgs.gov/wsp/1136/report.pdf.

Stumm, Werner, and Morgan, J.J., 1995, Aquatic chemistry: Chemical equilibria and rates in natural waters ( $3 \mathrm{~d}$ ed.):

New York, Wiley-Interscience, 1,041 p.
U.S. Environmental Protection Agency, 2009, Emerging contaminant-Tungsten, EPA 505-F-09-007, accessed August 12, 2010 at URL http://www.clu-in.org/download/ contaminantfocus/epa505f09007.pdf.

U.S. Environmental Protection Agency, 2011, Winter 2011 edition of the drinking water standards and health advisories: Washington, D.C., Office of Water, EPA 820-R-11002, 12 p., accessed May 20, 2011 at URL http://water.epa. gov/action/advisories/drinking/upload/dwstandards2011. $p d f$.

U.S. Geological Survey, 2007, Results of alkalinity calculator: U.S. Geological Survey web calculator, accessed July 17, 2008, at http://or.water.usgs.gov/cgi-bin/alk/calcalk.

U.S. Geological Survey, 2011, Current and historical LTMDL for Schedule 2238: U.S. Geological Survey NWQL Current and Historical Reporting Level Information, accessed October 28, 2011, at http://nwql.cr.usgs.gov/usgs/ltmdl/ ltmdl.cfm? $\mathrm{st}=s \& s s=2238$.

U.S. Geological Survey, variously dated, National field manual for the collection of water-quality data: U.S. Geological Survey Techniques of Water-Resources Investigations, book 9, chaps. A1-A9, available online at http://pubs.water.usgs. gov/twri9A.

U.S. Navy, 2010, NAS Patuxent River, MD Installation Guide, accessed September 29, 2010 at URL http://benfits.military. com/misc/installations/Base_Content.jsp? id=3115.

Vroblesky, D.A., and Fleck, W.B., 1991, Hydrogeologic framework of the Coastal Plain of Maryland, Delaware, and the District of Columbia: U.S. Geological Survey Professional Paper 1404-E, 45 p. 
Prepared by USGS West Trenton Publishing Service Center. Edited by Valerie M. Gaine.

Graphics and layout by Timothy W. Auer.

For additional information, contact:

Director, MD-DE-DC Water Science Center

U.S. Geological Survey

5522 Research Park Drive

Baltimore, MD 21228

or visit our Web site at:

http://md.water.usgs.gov 
